\author{
Nicolás Maquiavelo, \\ El principe, \\ traducción y prólogo de Emilio Blanco \\ Ariel Quintaesencia, Madrid, 2013, 200 p.
}

ISBN: 9788434406506

\title{
Jorge García
}

Universitat de Girona

jorge.garcia@udg.es

Este año de 2013 está siendo pródigo en centenarios en la hispanística tanto como en la italianística. Fue en 1613 cuando murió Traiano Boccalini y en el verano del mismo año comenzaron a circular los poemas mayores de Góngora, mientras que en ese mismo otońo ven la luz las Novelas ejemplares de Cervantes. Si retrocedemos un siglo, fue también durante un verano, en apenas unos meses, que debió escribirse una de las obras fundamentales del pensamiento político y probablemente una de las obras fundamentales del pensamiento humano, y desde luego la más alta expresión del Quattrocento. Ahora, durante el quinto centenario de aquel verano brillante, Il principe de Nicolás Maquiavelo aparece de nuevo en castellano en una valiosa traducción que merece comentario.

Nicolás Maquiavelo escribió durante el verano de 1513 su conocida obra como un intento casi desesperado por recobrar el favor de los Médicis y superar el ostracismo y la pobreza material a la que se vio obligado en el albergaccio de las afueras de Florencia, tras el golpe de estado de principios de septiembre de 1512 propiciado por los tercios de Folch de Cardona. Como tal, se trata de un documento cuasi privado, escrito en el estilo de los informes de la cancillería florentina, donde había sido Secretario cerca de 14 años. No es, pues, ni un tratado al uso, ni un ejercicio más o menos retórico sobre el poder político, sino el escrito de un político caído en desgracia y que quiere demostrar que sabe de qué habla y que puede hacer muy bien las cosas al servicio de los Médicis. Inscrito en unas coordenadas muy concretas de la Italia de los primeros ańos del siglo XVI y en medio de una fuerte inestabilidad política, cuya influencia se ha querido 
rastrear en los conceptos fundamentales del florentino, constituye una ruptura radical con el habitual y tradicional regimiento de príncipes medieval y humanista, basados ambos en el deber ser en el ejercicio del poder. Maquiavelo, por el contrario, pone toda su sabiduría y experiencia al servicio de los Médicis, como diplomático y estratega de la cosa pública, pero lo hace de una forma descarnada y partiendo de las necesidades reales de la política florentina e italiana del momento. El deber ser deviene así en una descripción real de los mecanismos del poder político, una forma de proceder que constituye el corazón del gran alcance teórico de la doctrina maquiaveliana. El prólogo de la edición, en apenas 15 páginas, nos muestra con detalle y agudeza, con un buen despliegue de títulos que no se suelen encontrar en las ediciones hispanas de la obra, esa diferencia esencial respecto del tradicional género del regimiento de príncipes, que estaban basados o en la moral cristiana o bien en utopías políticas de filiación platónica, a las que alude Maquiavelo en el famoso arranque del capítulo XV de la obra, cuando recuerda esas inexistentes repúblicas que llenan los libros de los autores clásicos. A partir de aquí el prólogo expone algunos de los conceptos y problemas centrales del texto, tales como la coyuntura o la virtud, que conforman el nervio del pensamiento del florentino (p. 12-13).

Todo ello desemboca en una obra singular y alejada de los contornos retóricos del ciceronianismo en alza en los ambientes humanistas desde mediados del siglo xv. La obra de Maquiavelo no está escrita de acuerdo con los cánones al uso, tal como resalta con gran acierto nuestra edición (p. 13-14), aunque sí los Discorsi. Y ello por la sencilla razón de que, en buena medida, Il principe es un documento escrito al uso de la cancillería florentina y a priori no pensado para circular en público, sino para ganarse el favor de los nuevos amos de Florencia. Pululan así los latinismos violentos, el lenguaje entrecortado, las afirmaciones tajantes y llamativas, la adjetivación radical, los consejos duros, la reflexión descarnada, la violencia de algunas expresiones o la sugerente vitalidad de la segunda persona, una serie de elementos que de forma paradójica convierten a $\mathrm{Il}$ principe en una obra maestra del estilo lacónico y sentencioso que buscaban los humanistas de la segunda mitad del siglo xvi en los autores de la Edad de Plata como Plinio el Joven o Tácito.

Ahora bien, que una obra maestra de semejante alcance y penetración se escriba en el lapso de un par de meses (posiblemente entre julio y septiembre de 1513, y ya aparece aludida en la famosa epístola a Francesco Vettori del 10 de diciembre de 1513) constituye un hecho que llama la atención. La explicación es sencilla y compleja al mismo tiempo. Maquiavelo había estado durante cerca de década y media al frente del gobierno florentino, había vivido innumerables coyunturas políticas y había acumulado una experiencia y un aparato conceptual derivado de la práctica política que puede rastrearse en un gran número de documentos técnicos de la cancillería florentina, donde ya vemos aflorar algunos de los principales conceptos que después articulan la obra maestra. Por ello, esos textos anteriores a Il principe suelen ser objeto de antologías que quieren explicar 
y mostrar la prehistoria de esos conceptos antes de llegar a los capítulos del tratado político. En castellano tenemos las colecciones de escritores políticos breves de María Teresa Navarro Salazar (Tecnos 1991) o la muy cuidada y esencial de Miguel Ángel Granada (Península, 1987, 2002). En este caso, el editor ha tenido el acierto de acompañar la traducción de Il principe con una versión castellana de los Capitoli, pequeñas composiciones en endecasílabos encadenados dedicadas a la Fortuna, la Ingratitud, la Ambición y la Ocasión, conceptos centrales de la obra maestra. El primero, por ejemplo, De la fortuna, dedicado a Soderini, su mentor en la cancillería, pone en pie una descripción de la diosa clásica que deviene una fuerza universal que gobierna la historia y de la que surge la virtù: «Si quieres poseer su buena estrella / trabaja lo posible en cada hora / de acompasarte al variar de aquella» (p. 160). Un acierto completo, pues, por parte de nuestra edición, el acompañar el texto de $I l$ principe con una serie de poemas en los que Maquiavelo va prefigurando algunos de sus conceptos políticos más importantes. Ese acierto es más notorio si pensamos que una parte de estos textos se publican por primera vez en castellano (p. 15-16 y 165-182).

Traducir a Maquiavelo no es fácil, debido a la misma naturaleza de la prosa de $I l$ principe, obra escrita a vuelapluma en unos meses. En general, las ediciones oscilan entre la fidelidad a un estilo entrecortado y una naturalización retórica más amplia. La opción intermedia elegida por el traductor de nuestra edición me parece la más acertada, modernizando el léxico que ha sufrido desplazamientos semánticos, dada la ausencia de notas, pero respetando términos como virtù, donde el pensamiento de Maquiavelo conquista su propia singularidad y personalidad, para que el lector español actual observe la polisemia de su vocabulario, reflejo de la hondura y la radicalidad de sus planteamientos, y la trabajosa definición de un espacio intelectual propio con los materiales que le ofrecía la tradición (p. 19-20). Por lo demás la traducción es ágil y cuidadosa, basada, como era de esperar, en las ediciones críticas de Giorgio Inglese, bien adaptadas en la puntuación y distribución de párrafos a las necesidades del lector hispano no especializado (p. 17-21). Acierto pleno también en la opción cuidadosamente matizada con que se traducen los versos del florentino mediante elegantes endecasílabos castellanos que, sin embargo, renuncian «a conservar la rima en aras de la fidelidad al texto» (p. 21). El texto va acompañado de una bibliografía breve, pero sustanciosa (p. 23-24), y de una serie corta de notas, tal como corresponde al tipo de edición y al público al que va dirigida, con la finalidad de recordar las formas latinas de los títulos de cada capítulo y señalar algunas fuentes clásicas.

Una valiosa traducción, pues, bien escoltada de textos relevantes y acompañada de una buena introducción que enriquece de forma notable el acervo de traducciones espańolas de Maquiavelo. 
